\title{
THE INFLUENCE OF FAMILY-RELATED FACTORS ON THE SUCCESSION PROCESS IN SMALL AND MEDIUM-SIZED FAMILY BUSINESSES
}

\author{
E Venter and $\mathbf{C}$ Boshoff
}

Department of Business Management, Nelson Mandela Metropolitan University

\begin{abstract}
In this study, family-related factors that can influence the succession process in small and mediumsized family businesses are empirically investigated. The dependent variable in this study is measured by two underlying dimensions, namely satisfaction with the process and continued profitability of the business. The empirical results indicate that the family-related factors that influence both the aforementioned dimensions are the mutual acceptance of roles, the relationship between the owner-manager and successor, and family harmony. The continued profitability of the business is also influenced by the agreement to continue the business. The existence of family harmony in itself influences the relationship between the owner-manager and successor, the agreement to continue the business, as well as the mutual acceptance of roles. The managerial implications of these empirical findings are discussed and recommendations offered.
\end{abstract}

JEL M51, M54

\section{1}

\section{Introduction}

Until recently, entrepreneurship and family business were almost unknown phenomena in most developed and developing economies and certainly did not receive the attention they deserve. It is only in recent years, when problems such as unemployment, underemployment and poverty started to cause social and political upheavals, that their true value and contribution were appreciated. Today it is acknowledged that family businesses are a primary contributor to the economic and social well-being of most economies in the world (IFERA, 2003; Sharma, 1997; Tan \& Fock, 2001; Ward, 2004). Their lack of longevity is, however, a cause for concern. One of the main reasons for this state of affairs is the inability of family businesses to manage the complex and emotion-laden process of ownership and management succession from one generation to the next (e.g. Magretta, 1998: 121; Matthews, Moore \& Fialko, 1999: 160).

According to Donnelley (1988: 428), family relationships influence succession by either facilitating or hindering succession planning and training (Lansberg \& Astrachan, 1994: 41). A variety of family-related factors can potentially impact on the succession process. For instance, if the choice of a successor from among the siblings is interpreted as parental favouritism, dysfunctional rivalries could be unleashed among brothers and sisters (Friedman, 1991: 11), which could complicate and delay the succession transition. Conversely, families that are mutually supportive and work well together, are more likely to effectively transfer the business to the next generation.

Although the relationship between the business leader and his or her successor is of the utmost importance, Santiago (2000) suggests that a more critical element for a smoother leadership transition is the relationship among family members. If the family members are not functioning harmoniously together, then the successor will not enjoy the acceptance and support needed to lead the business, even if the relationship between the successor and business leader is harmonious and both share the same management style (Santiago, 2000: 30). 
This study consolidates and integrates the existing literature on the various family-related factors that can influence succession in a theoretical model. The model is then empirically tested, using a relatively large sample of small and medium-sized family businesses. The empirical findings reveal important relationships that, if managed properly, can secure successful succession in these businesses and thus improve the longevity of small and medium-sized family businesses.

It must be emphasised that various definitions of family businesses exist. However, it is not the intention to discuss all these definitions because they do not form part of the focus for this research. In terms of this study, a family business is one that is owned by members of the same family to shape and/or pursue the formal or implicit vision of the business (which employs between five and 200 workers) and where it is the intention of family members to hand the business over to the next generation or where the business has already been handed over to a family member to manage and/or control. Family businesses that were unable or unwilling to hand over the business to the next generation in the near future, were excluded from this study. Family businesses that have gone through a succession process or are planning to do so in the near future are in the best position to express an opinion of those important factors that influence a successful succession process.

\section{2}

\section{The family-related factors that influence succession}

A major proportion of literature on family business has been devoted to understanding the influence of the family on the business (e.g. Danes, Rueter, Kwon \& Doherty, 2002; Dunn, 1999; Friedman, 1991; Handler, 1989; James, 1999; Lansberg \& Astrachan, 1994; Santiago, 2000; Seymour, 1993). The literature on family systems suggests that family structures and patterns of interaction can have an impact on the dynamics of family business management (Handler \& Kram, 1988: 365). As Davis (1983: 50) explains: "Families, as well as businesses, have their own system of organisation. The family system of organisation may maintain family cohesiveness and at the same time obstruct effective business management. It regulates the behavior of the family members through verbalised rules of conduct and highly restricted behavioral patterns that are unconsciously maintained".

The factors related to the family in family businesses that could directly influence succession that were investigated in this study are: the mutual acceptance of roles in the business by family members; the agreement by family members to continue the business; family harmony; and the relationship between the owner-manager and successor. Family harmony is also seen as an antecedent factor that could influence the other family-related factors, namely the relationship between the ownermanager and successor; agreement to continue the business; and mutual acceptance of roles.

\subsection{Mutual acceptance of individual roles}

Research by several authors has confirmed that the acceptance of individual roles in the context of the family business is an important variable that may influence the succession process (e.g. Habbershon \& Williams, 1999; Hume, 1999; Santiago, 2000). Empirical proof of this relationship is offered by Handler (1989: 163), Sharma (1997: 230) and Santiago (2000: 30), who argue that family members' acceptance of their relative position of power and responsibility in the family business will positively influence their satisfaction with the succession process and lead to a more successful process. It is accordingly hypothesised that:

$H^{1}$ : There is a positive relationship between the extent to which family members accept their individual roles in relation to the family business and the perceived success of the succession process

\subsection{Agreement to continue the business as a family business}

The commitment of the family to continue the business as a family business influences both 
the succession process (Lansberg \& Astrachan, 1994: 46; Seymour, 1993: 265) and the satisfaction of the successor with the succession experience (Handler, 1989: 249).

A positive relationship has been reported between succession planning and the extent of a family's commitment to the business, inter alia by the empirical results of Lansberg and Astrachan (1994: 52) and Seymour (1993: 267), as well as anecdotal evidence (Connolly \& Jay, 1996: 66; Lansberg, 1999: 332; Lea, 2000: 15). Similarly, Santiago (2000: 29) revealed that highly committed families view the business as a continuing legacy and are clear about the positive link between the longevity of the business and the well-being of the family. Ensuring the long-term vitality of the business is a central concern for such families. In her study, Handler (1992: 300) established that the greater the commitment to family business perpetuation as a family value, the more likely it is that the individual would have a positive succession experience (except when the commitment was to business means, rather than business ends). In their study, Chrisman, Chua and Sharma (1998: 23) found that respondents rated integrity and commitment to the business as important attribute variables. The studies of Dickinson (2000: 70) and Smyrnios, Tanewski and Romano (1998: 55) revealed that the family mission and family control are important issues in the commitment of a family to continue the business.

In contrast to these results, Sharma (1997: 231) found in her study that the commitment of the family to continue the business exerts no influence on the succession process. She strongly recommended that this variable be subjected to further testing by using different data sets to establish whether this factor does in fact have an influence on succession. In Sharma's study (1997: 234) the commitment to continue the business for both successors and founders was positively associated with payoffs from the business, but not perceived family harmony.

Despite the somewhat inconsistent findings, we hypothesised, based on the weight of empirical evidence, that:
$H^{2}$ : There is a positive relationship between the agreement among family members to continue the business as a family business and the perceived success of the succession process

\subsection{Family harmony}

While the acceptance of family members of their individual roles in the family business is important for successful succession, the literature suggests that the relationships between family members in general are also important for the succession process (Malone, 1989: 349; Sharma, 1997: 64). It can be argued that a high degree of harmony (e.g. mutual respect, trust, and understanding) within the family business may make succession planning a more tolerable task and that harmonious relationships may reinforce the importance of succession planning in the owner's mind.

Empirical support for the positive relationship between harmonious family relationships and its influence on the success of the succession process has been provided by various researchers (e.g. Morris, Williams, Allen \& Avila, 1997: 385; Santiago, 2000: 29). For example, the empirical results of Malone (1989: 349) revealed a positive correlation between perceived family harmony and continuity planning. The greater the family harmony, the higher the probability that business continuity will be planned for. These results are consistent with the findings of Handler (1994: 213), who observed a relationship between a positive succession experience and the mutual respect and understanding achieved by the next-generation family member with the predecessor in succession and an accommodatory approach (lack of conflict) between siblings regarding the family business.

Santiago (2000) contends that although succession planning aids leadership transition, it does not guarantee successful succession. The preservation of the family unit is more important than formal planning and helps to avoid the ill effects that normally accompany the absence of succession planning. A prerequisite for a smooth transition is that family members must be able to get along with 
one another within and outside the family business. It is therefore hypothesised that:

$H^{3}$ : There is a positive relationship between harmonious family relationships and the perceived success of the succession process.

However, Lansberg and Astrachan (1994) argue that family cohesion and adaptability have an indirect influence only on succession planning and training (through the family's commitment to the business and the quality of the work relationship between founder and successor). Their study could not empirically confirm that these family relationship variables exerted any direct influence on either succession planning or training. This finding led them to suggest that mediating variables should be used to understand the impact of family relationships on organisational behaviour (Lansberg \& Astrachan, 1994: 55; Sharma, 1997: 65). This argument is supported by the empirical results reported by Seymour (1993: 28), who found that the mediating variable family commitment to the business affected successor training and succession planning.

Sharma (1997: 233) also found that there is no relationship between perceived family harmony and the satisfaction with the succession process as experienced by incumbents. However, for both the founders and successors in her study perceived family harmony had a positive relationship with the extent of mutual acceptance of individual roles among family members, one of the mediating variables Sharma used.

Based on these arguments, it is suggested that family harmony has an indirect influence on the success of the succession process and has to be mediated by three factors: the acceptance among family members of their individual roles in relation to the family business, the family's agreement to continue the business, and the relationship between the owner-manager and successor (Lansberg \& Astrachan, 1994; Sharma, 1997). The following two hypotheses therefore need be considered:

$H^{4}$ : There is a positive relationship between family harmony and the acceptance of family members of their individual roles in the family business.
$H^{5}$ : There is a positive relationship between family harmony and the level of agreement among family members to continue the business.

\subsection{Relationship between owner- manager and successor}

Central to many literature reviews is the notion that the quality of the relationship between the outgoing leader and the successor is a critical determinant of the succession process (e.g. Chrisman et al., 1998: 19; Dickinson, 2000: 70; Lansberg \& Astrachan, 1994: 40). A highquality relationship is characterised by a high level of trust, mutual support, open and earnest communication, and willingness to acknowledge each other's achievements (Harvey \& Evans, 1995: 10; Neubauer \& Lank, 1998: 142; Seymour, 1993: 268).

Based on his empirical findings, Goldberg (1996) concluded that effective successors have significantly better relationships with their fathers (the owner-managers) than less effective successors - a finding that confirms previous research by Goldberg and Wooldridge (1993).

Whereas Handler (1989) included trust, support, communication, feedback, and mutual learning in her description of mutual respect and understanding, Sharma (1997: 233) only includes the element of trust in the successor's abilities as having an influence on the satisfaction with the succession process. Her results (Sharma, 1997) revealed that trust in the successor's abilities by the owner-manager had a significant influence on the satisfaction of stakeholders with the succession process. This partially confirms Handler's suggestion (1989: 48 ) that the quality of a successor's experience with the succession process is strongly influenced by the mutual respect and understanding between the founder and the nextgeneration family members.

A study by Stempler (1988: 80) of fifteen family-owned businesses indicated that respect, understanding, and complementary behaviour between the next-generation family member and the organisational leader are critical to effective succession. There was strong evidence that a sound understanding between successor and successee and catering to each other's needs 
affect the success of the succession. Handler's study (1989), which supports these findings, emphasised that mutual respect and understanding between the founder and nextgeneration family member is an important component of good succession outcomes. She further suggests that if the next-generation family members actively working in the family business are to be valued, the development of mutual respect must extend to non-family members as well (Handler 1989: 159).

On the basis of the above-mentioned review of the relationship between the owner-manager and successor and its influence on the succession process, the following hypothesis is formulated:

$H^{6}$ : There is a positive relationship between the nature of the relationship between the ownermanager and successor and the perceived success of the succession process.

\subsection{Family harmony and the relationship between the owner- manager and successor}

Seymour (1993: 276) reported a significant correlation between the quality of the work relationship and succession planning for ownermanager respondents, but not for successor respondents. Her results confirmed the model developed by Lansberg and Astrachan (1994), which suggests that the quality of the work relationship between owner-manager and successor mediates the association between successor training and both family cohesion and family adaptability. They do not expect an association between the quality of the work relationship and succession planning (Lansberg \& Astrachan, 1994: 54).

Based on these results, it was decided to again assess the influence of family relationships on the succession process, using as a mediating factor the relationship between owner-manager and successor, as suggested by Lansberg and Astrachan (1994) and Seymour (1993).

It is therefore hypothesised that:
$H^{7}$ : There is a positive relationship between family harmony and the relationship between the owner-manager and successor.

\subsection{The dependent variable}

There is still little consensus on what constitutes a successful or effective succession (Handler, 1989: 259; Santiago, 2000: 20; Stempler, 1988: 6). It has been suggested (Handler, 1989: 212; Morris et al., 1997: 390) that a distinction should be made between the quality of the experience (how family members personally experience the process) and the effectiveness of the succession (more objective assessments of the outcome of the transition). Others (for example Handler, 1989; Sharma, 1997; Stempler, 1988) have suggested that the satisfaction of predecessor, successor, and other family members with the succession process can be used as an indication of the perceived success of the succession process.

Goldberg (1996: 186), Harvey and Evans (1995: 12) and Hume (1999: 22) point out that not only the satisfaction of various stakeholders with the succession process defines a successful succession, but also the successor's ability to keep the family business healthy by means of sustained growth and continued profitability. Santiago (2000: 20) takes a more holistic view, and argues that if the leadership transition is so smooth that the change does not disrupt the family or the business, then the succession can be labelled successful.

It therefore appears that to ensure the success of the succession process, one requirement is that the various stakeholders involved in the process (the predecessor, successor, family, network, suppliers, etc.) must be satisfied with its outcomes, and the successor should have the ability to ensure the sustainability and financial security of the family business after the succession process has been completed.

The hypothesised inter-relationships among the various family-related variables that can influence the succession process are depicted in the theoretical model in Figure 1. 
Figure 1

Theoretical model of family-related factors that influence successful succession

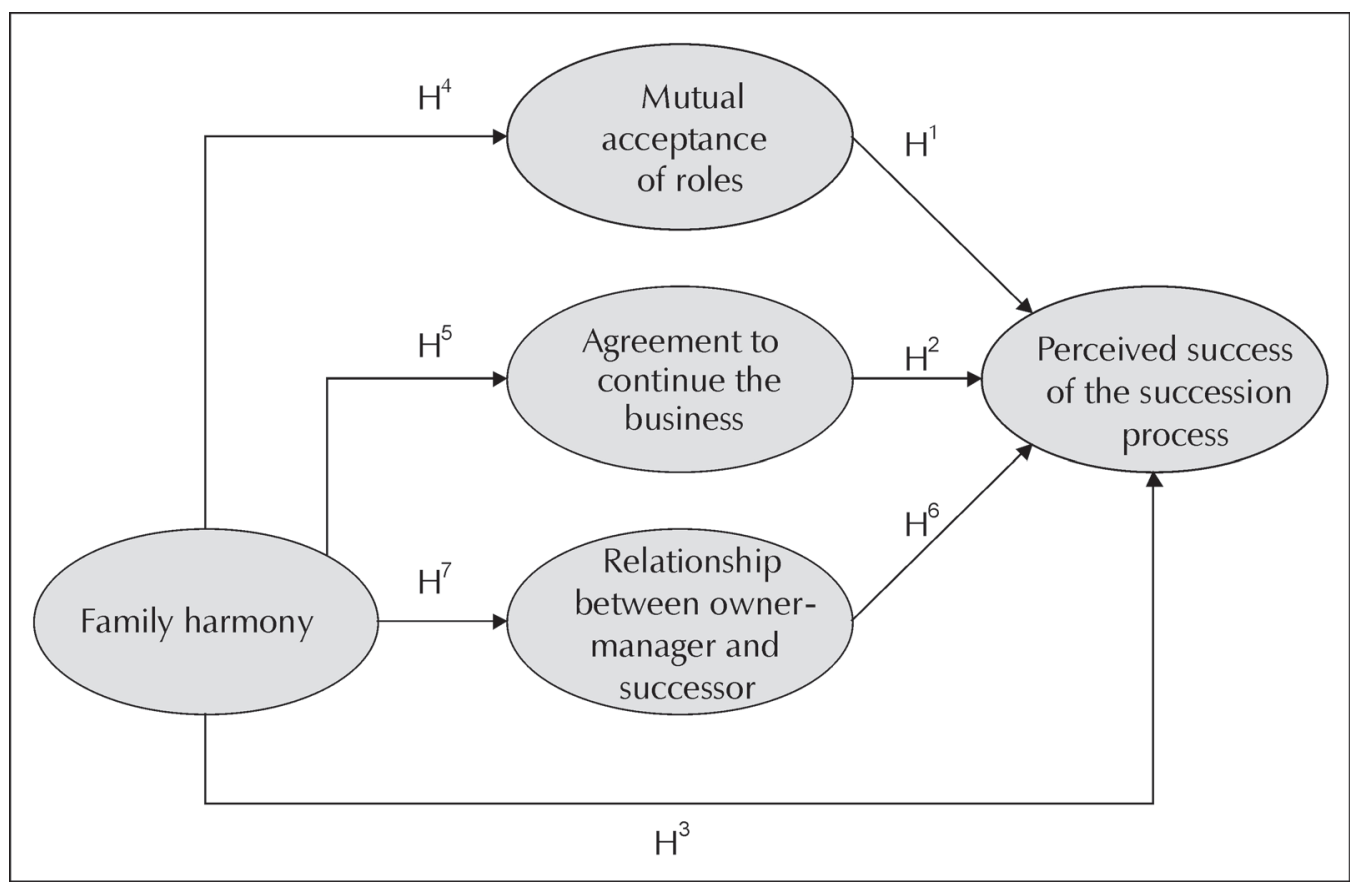

3

\section{Methodology}

\subsection{The measuring instruments}

All the latent variables included in the theoretical model were measured with multiitem instruments and all the items in the questionnaire were linked to a 7-point Likerttype scale. In this study, a six-item scale was used to measure the construct of family harmony, based on the scale developed by Sharma (1997). A scale of six items proposed by Lansberg and Astrachan (1994) was adopted as the base for measuring the relationship between the owner-manager and successor.

A seven-item scale was developed from the scales of Hume (1999), Lansberg and Astrachan (1994) and Sharma (1997) to measure the mutual acceptance of the individual roles of family members in the family business in this study. In the present study, a seven-item scale was developed to measure the agreement by family members to continue the family business, using a combination of scales utilised by Lansberg and Astrachan (1994), Sharma (1997) and Smyrnios et al. (1998).

In this study, an eleven-item scale was developed to measure the dependent variable, namely the perceived success of the succession process, based on the literature (see Goldberg, 1996; Handler, 1989; Morris et al., 1997; Santiago, 2000).

A list of the scales used in this study is presented in Annexure A.

\subsection{The sample}

This study was undertaken in South Africa among small and medium-sized family businesses. Numerous attempts were made to secure a mailing list of respondents in small and medium-sized family businesses in South Africa, but to no avail. Evidently considering such information a competitive advantage, large organisations with family businesses as clients (e.g. banks, insurance companies) chose not to co-operate in this study. 
To ensure that sufficient responses were obtained to permit the use of more robust statistical analysis techniques to analyse the data, a snowball sampling technique was used. Research associates were employed in the various regions of South Africa to contact small and medium-sized businesses in general, with the objective of identifying family businesses in particular. The potential respondents were also requested to identify other family businesses that could be approached. These referrals were subsequently contacted telephonically to confirm their contact details and test their willingness to participate in the study. Following up on referrals proved to be the most effective approach and eventually yielded the majority of the potential respondents listed on the sampling frame.

The final questionnaires were mailed to each of the 2458 respondents in the 1038 family businesses identified via the snowball sampling technique just described.. Each questionnaire was sent with a cover letter that guaranteed the anonymity of the respondents, as well as a return-paid envelope to make it as easy as possible for respondents to take part in the research.

A total of 332 usable questionnaires was returned. This was a more than adequate sample size given the number of parameters in the structural model to be estimated (Hair, Anderson, Tatham \& Black 1995: 637). The 332 questionnaires were split evenly between three of the four individual respondent groups, with 106 questionnaires received from potential successors, 103 received from successors, and 91 from retiring owner-managers. As can be expected, only 32 questionnaires were received from retired owner-managers, as they were more difficult to reach by virtue of the fact that they had already retired and left the business, or were deceased.

\subsection{Description of the realised sample}

Altogether 34 per cent of respondents had businesses that employed less than ten employees, and a further 30 per cent employed between ten and nineteen employees. Only 6 per cent employed more than 100 (but not more than 200) employees. These findings are consistent with the findings from previous research and suggestions from literature that the majority of SMEs in South Africa employ less than twenty people (Laubscher, 1993: 96; Maas, 1999: 3).

Possibly as a function of the sampling technique employed, almost half the respondents (49 per cent) were in the agricultural sector, with 23 per cent in the retailing and 19 per cent in the service industry.

Considering that the majority of respondents were either successors ( 31 per cent) or potential successors ( 32 per cent), most of the respondents were from the non-founding generation, with 47 per cent from the second generation and 18 per cent from the third generation. However, 23 per cent of respondents were still from the founding (first) generation.

By far the greater majority of respondents ( 81 per cent) indicated that their families owned a controlling share in the business (more than 50 per cent) and that between two and four family members were employed on a full-time basis. Sole proprietorship at 29 per cent and close corporations at 27 per cent were the most prevalent business forms.

Most current owner-managers were European (97 per cent) and male ( 90 per cent), while only 11 per cent of the potential successors were identified as female.

\subsection{The statistical analyses of the data}

The analysis of the data consisted of four phases. Initially the data were subjected to a comprehensive exploratory factor analysis (CEFA) to assess the discriminant validity and construct validity of the measuring instrument. Items that did not demonstrate sufficient validity were deleted before the next data analysis phase commenced. The reliability of the instrument was assessed by means of an internal consistency measure (Cronbach Alpha). Again, items whose removal could enhance the reliability of the data were deleted. The items that remained in the theoretical model were then subjected to a confirmatory factor analysis to assess the fit of the measurement model in line with Anderson and Gerbing's (1988) recommendation of using 
a "two-step approach" of model testing. Only once the measurement model has been found appropriate, should one proceed to test the structural model.

\section{4}

\section{The empirical results}

\subsection{Discriminant and construct validity assessment}

A comprehensive exploratory factor analysis (CEFA) was conducted to assess the discriminant and construct validity of the measuring instruments used in this study. For this purpose the CEFA programme developed by Browne, Cudeck, Tateneni and Mels (1998) was used. CEFA is a programme that performs exploratory factor analyses with various rotation options and also computes standard error estimates for all parameters. Previously, when conducting an exploratory factor analysis the rule of thumb of what constitutes a significant factor loading was no more than conjecture. Over time, a factor loading of 0.4 has more or less become the accepted norm of what constitutes a "significant" factor loading (Hair et al., 1995: 385). The use of CEFA negates this "thumb suck" norm and allows the analyst to assess significance on purely statistical grounds. The standard error estimates are used to construct 90 per cent confidence interval estimates for every rotated factor loading. To assess the significance of a factor loading the null hypothesis is:

\section{HO: Factor loading $=0$}

This null hypothesis is rejected when the 90 per cent confidence interval estimate does not overlap zero. In this study, a factor loading is regarded as practically significant if the lower bound of the corresponding 90 per cent confidence interval is greater than 0.1 or if the upper bound of the corresponding 90 per cent confidence interval is less than -0.1 . Otherwise, it is regarded as practically insignificant. The quartimax rotated factor matrix for the independent variables is reported in Table 1 and for the dependent variable in Table 2.

Table 1

Quartimax rotated factor matrix: The independent variables

\begin{tabular}{|c|c|c|c|c|}
\hline Items & Family harmony & $\begin{array}{c}\text { Relationship between } \\
\text { owner-manager } \\
\text { and successor } \\
\text { (Relate) }\end{array}$ & $\begin{array}{c}\text { Agreement to } \\
\text { continue the } \\
\text { business } \\
\text { (Agree) }\end{array}$ & $\begin{array}{c}\text { Mutual acceptance } \\
\text { of roles }\end{array}$ \\
\hline FH1 & $\mathbf{0 . 6 7 3}$ & -0.078 & 0.075 & 0.083 \\
\hline FH2 & $\mathbf{0 . 5 2 1}$ & -0.004 & 0.103 & 0.059 \\
\hline FH3 & $\mathbf{0 . 7 5 1}$ & 0.107 & -0.064 & 0.048 \\
\hline FH4 & $\mathbf{0 . 9 2 0}$ & -0.022 & -0.083 & -0.017 \\
\hline FH6 & $\mathbf{0 . 8 1 2}$ & 0.053 & 0.005 & -0.013 \\
\hline REL4 & 0.047 & $\mathbf{0 . 8 1 8}$ & -0.106 & 0.035 \\
\hline REL5 & -0.041 & $\mathbf{0 . 5 5 8}$ & 0.018 & 0.053 \\
\hline REL6 & 0.268 & $\mathbf{0 . 5 1 7}$ & -0.010 & -0.017 \\
\hline REL7 & -0.094 & $\mathbf{0 . 8 3 4}$ & 0.108 & 0.037 \\
\hline AGR2 & -0.056 & -0.064 & $\mathbf{0 . 5 5 4}$ & 0.103 \\
\hline AGR4 & 0.185 & 0.173 & $\mathbf{0 . 4 7 5}$ & 0.035 \\
\hline AGR6 & 0.064 & -0.045 & $\mathbf{0 . 5 1 3}$ & 0.090 \\
\hline
\end{tabular}




\begin{tabular}{|c|c|c|c|c|}
\hline AGR7 & -0.028 & 0.055 & $\mathbf{0 . 5 0 8}$ & -0.138 \\
\hline MAR1 & 0.146 & -0.034 & -0.008 & $\mathbf{0 . 7 1 7}$ \\
\hline MAR2 & -0.073 & 0.011 & -0.010 & $\mathbf{0 . 8 7 1}$ \\
\hline MAR3 & 0.025 & 0.184 & 0.064 & $\mathbf{0 . 4 9 1}$ \\
\hline MAR6 & 0.217 & 0.086 & 0.159 & $\mathbf{0 . 4 5 8}$ \\
\hline MAR7 & 0.237 & 0.170 & -0.071 & $\mathbf{0 . 4 0 7}$ \\
\hline
\end{tabular}

Where:

$\begin{array}{lll}\mathrm{FH} & = & \text { Family harmony } \\ \mathrm{REL} & = & \text { Relationship between owner-manager and successor } \\ \mathrm{AGR} & = & \text { Agreement to continue the business } \\ \mathrm{MAR} & = & \text { Mutual acceptance of roles in the business }\end{array}$

Table 2

Quartimax rotated factor matrix: The dependent variables

\begin{tabular}{|c|c|c|}
\hline Items & \multicolumn{2}{|c|}{ Factors } \\
\hline & $\begin{array}{c}\text { Satisfaction with the } \\
\text { succession process } \\
\text { (Satisfied) }\end{array}$ & Continued profitability \\
\hline SUC5 & $\mathbf{0 . 7 6 1}$ & -0.016 \\
\hline SUC6 & $\mathbf{0 . 6 2 2}$ & 0.137 \\
\hline SUC7 & $\mathbf{0 . 5 2 8}$ & 0.178 \\
\hline SUC8 & $\mathbf{0 . 8 1 2}$ & -0.138 \\
\hline SUC3 & $\mathbf{0 . 6 2 1}$ & 0.077 \\
\hline SUC1 & -0.053 & $\mathbf{0 . 8 3 1}$ \\
\hline SUC2 & 0.168 & $\mathbf{0 . 4 6 8}$ \\
\hline SUC4 & 0.065 & $\mathbf{0 . 2 6 3}$ \\
\hline SUC10 & -0.063 & $\mathbf{0 . 7 6 8}$ \\
\hline
\end{tabular}

Where:

SUC $=$ Perceived success of the succession process

Both Tables 1 and 2 are the result of successive CEFA procedures that led to the elimination of individual items if they did not meet the significance criteria set out above. The final outcome is that all the remaining items reported in both Tables 1 and 2 reveal statistically significant loadings and each item loads to a significant extent on only one factor, suggesting a high level of discriminant and construct validity.

Table 2 shows that the items expected to load on one dependent variable did in fact split into two factors. It implies that, at least for this sample, the construct successful succession is not uni-dimensional. Successful succession, in this instance, consists of two underlying dimensions, namely satisfaction with the succession process and continued profitability of the business. The CEFA results reported in Table 1 and 2 necessitated a revision of the original theoretical model.

Once the discriminant and construct validity of the instruments and the resultant data had been ascertained, the next step was to assess the measurement model by means of a confirmatory factor analysis (CFA). 


\subsection{The measurement model}

An inspection of the distributional properties of the data revealed that the assumption of multivariate normality does not hold true for this data set. As a result, Robust Maximum Likelihood (RML) estimation was used as recommended by Jöreskog and Sörbom (2003).

The fit of the CFA model $\left(\chi^{2}=466.55 ; \mathrm{df}=\right.$ $309 ;$ p-value $=0.00000 ;$ RMSEA $=0.039)^{1}$ and particularly the RMSEA of 0.039 suggest that the measurement model fitted the data closely (Steiger \& Lind, 1980). The low $\chi^{2} / \mathrm{df}$ ratio of 1.50 is further evidence of a well-fitting model, especially if one considers that the upper limit of the 90 per cent Confidence Interval for the RMSEA was substantially lower (0.0463) than the recommended 0.08 . In addition, the modification indices did not suggest the need for any changes to the model.

\subsection{The structural model}

The final data analysis phase was to statistically assess the hypothesised relationships depicted in the structural model. The results are graphically depicted in Figure 2. Although the fit indices for the model suggest a reasonable fit $\left(\chi^{2}=906.32 ;\right.$ df $=313 ;$ p-value $=0.00000 ;$ RMSEA $=0.076)^{1}$ of the model to the data, one has to keep in mind that the objective was to asses the relationships among the variables and not to obtain a well-fitting model.

The path coefficients reported in Figure 2 show that the dependent variable continued profitability of the business is strongly influenced by mutual acceptance of roles $(0.644$, $\mathrm{p}<0.001)$, agreement to continue the business $(0.368, \mathrm{p}<0.001)$ as well as the relationship between the owner-manager and successor $(0.239, \mathrm{p}<0.01)$. The relationship is positive in all three cases. In other words, the greater the mutual acceptance of the various roles among family members working in the business, the more the various parties agree to continue the business and the better the relationship between the owner-manager and the successor(s), the more likely it is that the business will remain profitable after succession has taken place. Hypotheses $\mathrm{H}^{1}, \mathrm{H}^{2}$ and $\mathrm{H}^{6}$ can thus be accepted with regards to the dependent variable continued profitability of the business.

Figure 2 also shows that continued profitability of the business is strongly influenced by family harmony, although this relationship is negative $(-0.383 ; p<0.01)$. This would suggest that the business is less likely to continue to be profitable if there is a considerable degree of harmony among family members. Hypothesis $\mathrm{H}^{3}$ is thus rejected with regard to the dependent variable continued profitability of the business. The dependent variable satisfaction with the succession process is positively influenced by mutual acceptance of roles $(0.573, \mathrm{p}<0.001)$, the relationship between owner-manager and successor $(0.204, \mathrm{p}<0.001)$ and family harmony $(0.255, \mathrm{p}<0.01)$. In other words, the more there is mutual acceptance of the various roles among family members working in the business, the better the relationship between the ownermanager and the successor and the better the general harmony within the family, the more satisfied the family members will be with the succession process. There is, however, no relationship between satisfaction with the succession process and agreement to continue the business. Hypotheses $\mathrm{H}^{1}, \mathrm{H}^{3}$, and $\mathrm{H}^{6}$ can thus be accepted as far as satisfaction with the succession process is concerned, but not Hypotheses $\mathrm{H}^{2}$

Figure 2 further shows that the variable family harmony positively influences mutual acceptance of roles $(0.766, \mathrm{p}<0.001)$, agreement to continue the business $(0.400, \mathrm{p}<0.001)$ and the relationship between owner-manager and successor $(0.539, \mathrm{p}<0.001)$. This would suggest that the greater the harmony within the family, the more acceptance there will be of the various roles, the more agreement there will be to continue the business and the better the relationship will be between the owner-manager and the successors. Hypotheses $\mathrm{H}^{4}, \mathrm{H}^{5}$ and, $\mathrm{H}^{7}$ are thus all accepted. 
Figure 2

Structural model

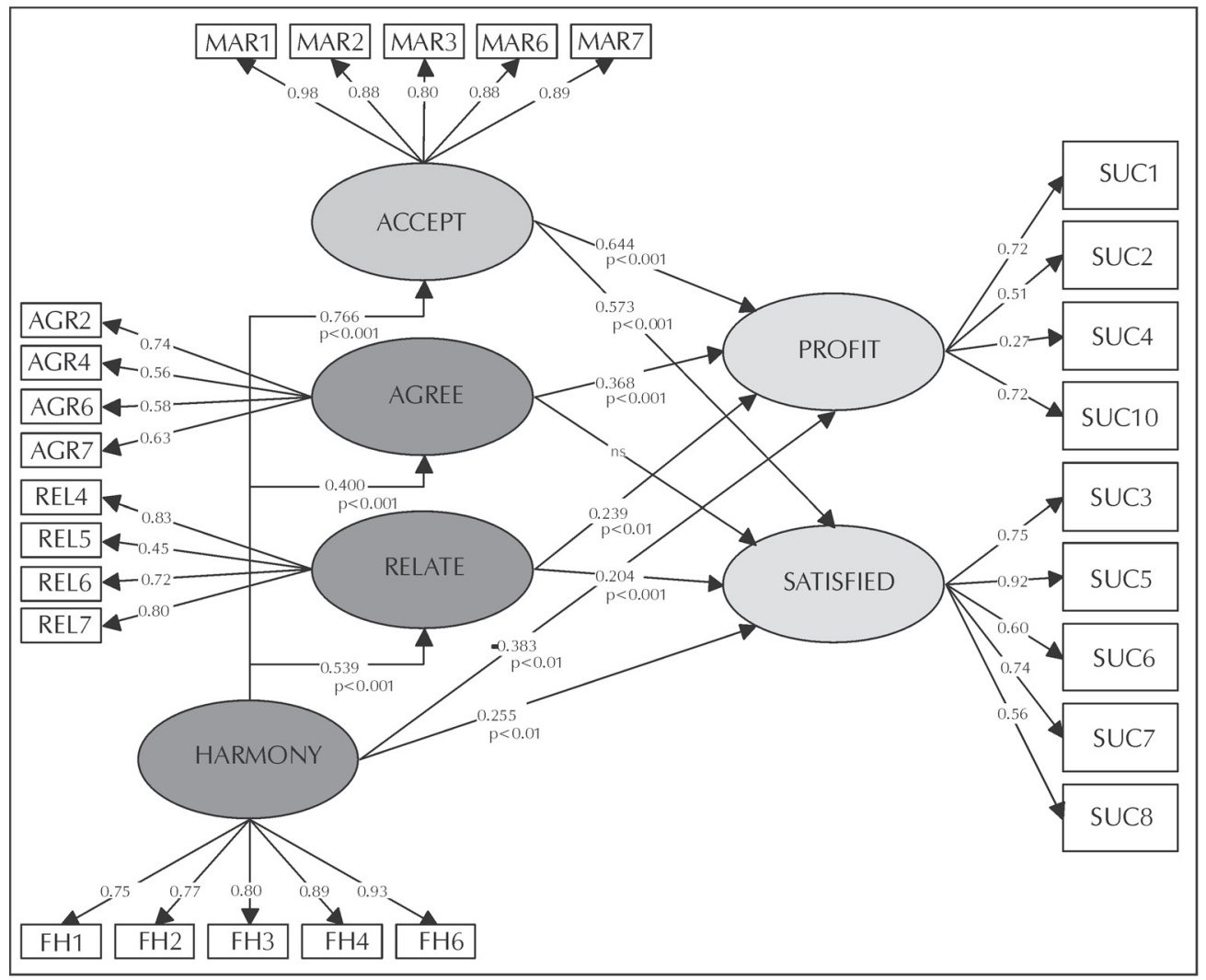

Where:

ACCEPT = Mutual acceptance of roles

AGREE $=$ Agreement to continue the business

RELATE = Relationship between owner-manager and successor

HARMONY = Family harmony

PROFIT = Continued profitability of the business

SATISFIED $=$ Satisfaction with the process

\section{5}

\section{Conclusion and recommendations}

\subsection{Family harmony}

Respondents in this study indicated that the degree of family harmony that exists in the family will have a significantly positive effect on family members' satisfaction with the process and a significant negative effect on their perception of the continued profitability of the business. Harmonious family relationships also significantly influence the degree to which family members accept their roles in the context of the family members, the relationship between the ownermanager and successor, and agreement by family members to continue with the business. Family members who trust, respect, appreciate and care for each other are likely to co-operate with each other and support each other's decisions, both in the family unit itself and in the family business. It was confirmed in the current study that family harmony has a direct positive influence on the satisfaction with the succession process. 
It can be argued that a high degree of harmony within the family may make it easier to discuss succession issues and set up appropriate systems for preparing the next generation to take over the family business, generally making succession a more tolerable task. Valuing the preservation of the family unit could help to avoid the ill effects that may accompany the absence of succession planning. A family in conflict may find the succession task very difficult.

However, over-emphasis of harmony may endanger the free flow of business ideas. In a family business that over-emphasises family harmony, cordial personal relationships among relatives may take precedence over the maximum profits generated from the business. If a certain amount of tension is required for the business, too great an emphasis on harmony could conceivably result in very harmonious families, but under-performing businesses. That may explain the negative direct relationship between family harmony and future profitability in Figure 2. One must appreciate, however, that family harmony also exerts an indirect positive influence on future profitability. Figure 2 shows, however, that positive outcome on future profitability is only possible if it is mediated by the degree to which family members accept their roles in the context of the family members, the relationship between the owner-manager and successor, and agreement by family members to continue with the business.

One has to accept that it is not always possible to avoid conflict regarding the sensitive issue of succession. The family business requires that the family, as a unit, develops internal processes and mechanisms to confront and resolve its own emotional issues. This process will generally be facilitated by a clear division of responsibilities and an agreement on functional roles among family members to prevent them from transgressing on each other's turf. Alternatively, the services of an external mediator could be hired to resolve inter-familial conflict.

\subsection{Relationship between the owner- manager and the successor}

This study established that the relationship between the owner-manager and the successor had a significant influence on the respondents' satisfaction with the succession process, as well as the continued profitability of the business. This result again stresses the importance of establishing and managing a high-quality and harmonious owner-manager-successor relationship, in which the two generations support each other and are willing to share information.

A cordial relationship between the ownermanager and the successor stems from mutual respect for and understanding of each other's accumulated knowledge and skills. Since the two parties will be at different stages in their lives, it is most likely that they will have different priorities and view the business from different perspectives. To avoid conflict, both parties should be willing to communicate openly and honestly and share business information and ideas with each other. Parents should be flexible enough to explore and accept new managerial approaches and should treat their children as adults, allowing them to contribute to decisionmaking. Such treatment will build confidence and develop healthy relationships, based on trust and support.

Lansberg (1999: 126) suggests that one of the most important determinants of successful succession is whether the senior leader and the new leader enjoy a relationship beyond the work environment. This implies that the outgoing leader and the new leader should explore and share activities outside the context of the family business that can bring them closer together.

\subsection{Mutual acceptance of roles}

The extent to which respondents in this study accept their relative levels of power and responsibilities inside the family business will influence both their satisfaction with the process and their perception of the continued profitability of the business. Educating the family to understand the rights and responsibilities that come with the various roles that they may assume in the future is one of the basic tasks associated with succession planning (Lansberg, 1988: 135). Role conflicts and commitment to multiple constituencies are common problems in family businesses. 
Most individuals prefer their roles and responsibilities in the business to be clearly defined. Such clarity helps individuals to identify with their contributions and responsibilities and perceive a sense of fairness in their employment (Sharma, 1997: 62). Although the degree of clarity about roles may vary in different families and different mechanisms may be adopted to establish clear roles and responsibilities for family members, it is ultimately the acceptance among family members of the level of involvement of both the owners and managers in the business that determines their satisfaction with the succession process (Sharma, 1997: 63). Santiago (2000: 30 ) claims that among siblings, acceptance of a likely successor is an indication of their acceptance of their relative position of responsibility and power.

\subsection{Agreement to perpetuate the family business}

Ensuring the long-term vitality of the business is a central concern for committed families. The respondents in this study indicated that it would influence the continued profitability of the business, as family members will probably work harder if they are committed to continue the business as a family business. As a result, they view succession planning not only as a specific set of managerial tasks, but as an activity that must be executed for the greater good of the family. Family commitment is particularly critical to the owner-manager, whose direct involvement with the planning process is imperative. Highly committed families view the business as a continuing legacy (Santiago, 2000: 30 ) in which the family's traditions, identity and culture are embodied and they are clear about the positive link between the longevity of the business and the well-being of the family.

By contrast, low-commitment families are less concerned with business survival. In such family businesses, communication about the business is discouraged and the children are directed to pursue activities and careers outside the family business. Handler (1989: 176) has, however, warned that in certain cases, family business perpetuation may have a negative effect on succession outcomes. The passing on of norms or traditions of operating the business from generation to generation could have a detrimental effect on the organisation and the individuals involved. For example, family traditions are often the reason why many family businesses are slow to modernise by adopting new technology and more formalised systems.

\section{6}

\section{Summary, limitations and recommendations for future research}

This is one of the few studies that empirically assess an integrated model of the successorrelated factors impacting on the succession process in small and medium-sized family businesses. Using a fairly large sample, it addresses much of the uncertainty that still reigns on the critical factors that influence succession and in this way enhances our understanding of the succession process, as called for by Sharma (1997: 4), Morris et al. (1997: 385) and others. It can be regarded as a small step towards moving away from the current dependence on anecdotal evidence, case studies and small-scale descriptive studies.

Although the present study attempted to make a significant contribution to the body of knowledge on succession in small and mediumsized family businesses, certain areas are still in need of further investigation. Using a convenience sample (due to the lack of a compre-hensive database on family businesses in South Africa) was a limitation of this study, as findings could not be generalised. It would also be worth pursuing the question whether culture itself affects family business management in general, and succession in particular.

As this research presents a generic model of family-related factors that influence the succession process in family businesses, future research could confirm, based on larger empirical samples, to what extent the perceptions of the succession process are different among various generations of family members. For instance, factors perceived to be 
important to the succession process may differ when comparing the views of owner-managers with those of successors, or comparing family businesses that have already completed a succession to those that have not.

Another limitation is that this study relied completely on respondents' perceptions. To close the gap between perception and reality, future research could be designed to collect field data on what is actually done when family businesses plan for succession. In-depth interviews with those involved in small and medium-sized family businesses could contribute further to the validation (or rejection) of some of the variables that contributed to the success of the succession process our study.

Given the homogeneous nature of the demographic characteristics of the respondents in this study, particularly with regard to gender and ethnicity, the impact of demographic factors on both the perceived success of the succession process and those factors that influence the process, should be further investigated.

\section{Footnote}

1) The Robust Maximum Likelihood (RML) estimation was used to assess the model. As RML does not assume multivariate normality, the reporting of the GFI and AGFI indices is inappropriate. The reported $\div^{2}$ is the SatoraBentler value, which is the most appropriate for the RML estimation used in this study.

\section{References}

1 ANDERSON, R.E. \& GERBING, D. (1988) In Hair, J.F., Anderson, R.E., Tatham, R.L., and Black, W.C. (eds.) (1998) Multivariate Data Analysis (5 ${ }^{\text {th }}$ ed.) Prentice Englewood Cliffs, Prentice Hall: New Jersey.

2 BROWNE, M.W.; CUDECK, R.; TATENENI, K. \& MELS, G. (1998) CEFA: Comprehensive Exploratory Factor Analysis, User's Manual.

3 CHRISMAN, J.J.; CHUA, J.H. \& SHARMA, P. (1998) "Important attributes of successors in family businesses: An exploratory study", Family Business Review, 12(1): 19-34.
4 CONNOLly, G. \& JAY, C. (1996) The Private World of Family Business, Pearson Professional (Australia). From 1997, published and distributed by Woodslane, NSW, Australia.

5 DANES, S.M.; RUETER, M.A.; KWON, H. \& DOHERTY, W. (2002) "Family FIRO model: An application to family business", Family Business Review, 15(1): 31-43.

6 DAVIS, P. (1983) "Realizing the potential of the family business", Organisational Dynamics, Summer, 12: 47-56.

7 DICKINSON, T.M. (2000) "Critical success factors for succession planning in family businesses", Unpublished research report in partial fulfillment of the degree of Master in Business Administration, Faculty of Business Administration, University of the Witwatersrand, Johannesburg.

8 DONNELLEY, R.G. (1988) "The family business", Family Business Review, 1(4): 427-445.

9 DUNN, B. (1999) "The family factor: The impact of family relationship dynamics on business-owning families during transitions", Family Business Review, 12(1): 41-60.

10 FRIEDMAN, S.D. (1991) "Sibling relationships and intergenerational succession in family firms", Family Business Review, 4(1): 3-20.

11 GOLDBERG, S.D. (1996) "Research Note: Effective successors in family-owned businesses: significant elements", Family Business Review, 9(2): 185-197.

12 GOLDBERG, S.D. \& WOOLDRIDGE, B. (1993) "Self-confidence and managerial autonomy: Successor characteristics critical to succession in family firms", Family Business Review, 6(1): 55-73.

13 HABBERSHON, T.G. \& WILLIAMS, M.L. (1999) "Resource-based framework for assessing the strategic advantages of family firms", Family Business Review, 12(1): 1-26.

14 HAIR, J.F.; ANDERSON, R.E.; TATHAM, R.L. \& BLACK, W.C. (1995) Multivariate Data Analysis: With Readings, Englewood Cliffs, Prentice Hall: New Jersey.

15 HANDLER, W.C. (1989) "Managing the family firm succession process: The next-generation family member's experience", Unpublished doctoral thesis, Boston University, Boston.

16 HANDLER, W.C. (1992) "The succession experience of the next generation", Family Business Review, 5(3): 283-307.

17 HANDLER, W.C. (1994) "Succession in family businesses: A review of the research", Family Business Review, 7(2): 133-157. 
18 HANDLER, W.C. \& KRAM, K.E. (1988) "Succession in family firms: The problem of resistance", Family Business Review, 1(4): 361381.

19 HARVEY, M. \& EVANS, R.E. (1995) "Life after succession in the family business: Is it really the end of problems?", Family Business Review, 8(1): 3-16.

20 HUME, S.A. (1999) "An assessment of the risk of family business failure", Unpublished doctoral thesis, Antioch University, New Hampshire.

21 IFERA. (2003) "Family business dominate". Family Business Review, 16(4): 235-240.

22 JAMES, H.S. (1999) "What can the family contribute to business? Examining contractual relationships", Family Business Review, 12(1): 6171.

23 LANSBERG, I. (1999) Succeeding Generations: Realising the Dreams of Families in Business, Harvard Business School Press: Boston.

24 LANSBERG, I. \& ASTRACHAN, J.H. (1994) "Influence of family relationships on succession planning and training: the importance of mediating factors", Family Business Review, 7(1): 39-59.

25 LAUBSCHER, I. (1993) "An explorative investigation into the nature and scope of the relationship between the founder and successor in a family business with regard to succession", Unpublished Master's research report, Graduate School of Business University of Stellenbosch: Stellenbosch.

26 MAAS, G. (1999) "Family businesses in South Africa: A development model", Paper presented at the Saesba Conference, July 30 - August 1, 115.

27 MATTHEWS, C.H., MOORE, T.W. \& FIALKO, A.S. (1999) "Succession in the family firm: A cognitive categorization perspective", Family Business Review, 12(2): 159-169.

28 LEA, J.W. (2000) "Succession planning requires family teamwork". The Business Journal of the Twin Cities, 17(37): 14-16.
29 MAGRETTA, J. (1998) "Governing the familyowned enterprise: An interview with Finland's Krister Ahlström", Harvard Business Review, January/February: 113-123.

30 MALONE, S.C. (1989) "Selected correlates of business continuity planning in the family business", Family Business Review, 2(4): 341-353.

31 MORRIS, M.H.; WILLIAMS; R.W., ALLEN, J.A. \& AVILA, R.A. (1997) "Correlates of success in family business transitions", Journal of Business Venturing, 12: 385-401.

32 NEUBAUER, F. \& LANK, A.G. (1998) The Family Business - Its Governance for Sustainability, routledge: new york.

33 SANTIAGO, A.L. (2000) "Succession experiences in Philippine family businesses", Family Business Review, 8(1): 15-40.

34 SEYMOUR, K.C. (1993) "Intergenerational relationships in the family firm: The effect on leadership succession", Family Business Review, 6(3): 263-281.

35 SHARMA, P. (1997) "Determinants of the satisfaction of the primary stakeholders with the succession process in family firms", Unpublished doctoral thesis, University of Calgary: Canada.

36 SMYRNIOS, K.; TANEWSKI, G. \& ROMANO, C. (1998) "Development of a measure of the characteristics of family business", Family Business Review, 11(1): 49-60.

37 STEIGER, J. H. \& LIND, J.C. (1980) "Statistically based tests for the number of common factors", Paper read at the annual meeting of the Psychometric Society: Iowa City.

38 STEMPLER, G.L. (1988) "A study of succession in family owned businesses", Unpublished doctoral thesis, The George Washington University: Washington.

39 TAN, W. \& FOCK, S. (2001) "Coping with growth transitions: The case of Chinese family businesses in Singapore", Family Business Review, 14(2): 123-139.

40 WARD, J.L. (2004) Perpetuating the Family Business, Palgrave Macmillan: New York. 
Annexure A: Scales used in this study*

\begin{tabular}{|c|c|}
\hline $\mathrm{FH} 1$ & During the succession process our family members cared about each other's welfare \\
\hline $\mathrm{FH} 2$ & During the succession process our family members emotionally bonded with each other \\
\hline $\mathrm{FH} 3$ & During the succession process our family members trusted each other \\
\hline $\mathrm{FH} 4$ & During the succession process our family members respected each other \\
\hline FH6 & During the succession process our family members appreciated each other \\
\hline REL4 & $\begin{array}{l}\text { During the succession process the retired owner-manager and I had a mutually supportive } \\
\text { relationship }\end{array}$ \\
\hline REL5 & $\begin{array}{l}\text { During the succession process I preferred to cooperate with the retired owner-manager rather than } \\
\text { compete with him/her }\end{array}$ \\
\hline REL6 & $\begin{array}{l}\text { During the succession process the retired owner-manager and I freely shared our business-related } \\
\text { opinions with each other }\end{array}$ \\
\hline REL7 & $\begin{array}{l}\text { During the succession process the retired owner-manager and I were willing to share information } \\
\text { with each other }\end{array}$ \\
\hline AGR2 & $\begin{array}{l}\text { During the succession process a major objective of the family business was to pass it on to the next } \\
\text { generation }\end{array}$ \\
\hline AGR4 & During the succession process I was deeply committed to continuing the family business \\
\hline AGR6 & The retired owner-manager wanted his/her children to be involved in the family business \\
\hline AGR7 & $\begin{array}{l}\text { If none of the next generation of family members joined the family business, the retired owner- } \\
\text { manager would have been very disappointed }\end{array}$ \\
\hline MAR1 & During the succession process family members accepted their roles and positions in the business \\
\hline MAR2 & $\begin{array}{l}\text { During the succession process family members understood their specific responsibilities in the } \\
\text { business }\end{array}$ \\
\hline MAR3 & $\begin{array}{l}\text { During the succession process family members in the business freely expressed their opinions about } \\
\text { the business }\end{array}$ \\
\hline MAR6 & $\begin{array}{l}\text { During the succession process family members encouraged each other to produce their best efforts } \\
\text { in the business }\end{array}$ \\
\hline MAR7 & $\begin{array}{l}\text { During the succession process conflict between family members involved in the business was } \\
\text { effectively resolved }\end{array}$ \\
\hline SUC5 & All family members involved in the family business are satisfied with the succession process \\
\hline SUC6 & I am satisfied with the succession process \\
\hline SUC7 & $\begin{array}{l}\text { The family supports the family business after the management/leadership of the business was } \\
\text { handed over to me }\end{array}$ \\
\hline SUC8 & The retired owner-manager is satisfied with the succession process \\
\hline SUC3 & $\begin{array}{l}\text { The relationships among family members are positive after the management/leadership of the } \\
\text { business was handed over to me }\end{array}$ \\
\hline SUC1 & $\begin{array}{l}\text { The family business has performed as well or better since the management/leadership of the } \\
\text { business was handed over to me }\end{array}$ \\
\hline SUC2 & $\begin{array}{l}\text { The family business has proved to be sustainable since the management/leadership of the business } \\
\text { was handed over to me }\end{array}$ \\
\hline SUC4 & $\begin{array}{l}\text { The relationships with stakeholders (networks, suppliers, etc.) are intact after the management or } \\
\text { leadership of the business was handed over to me }\end{array}$ \\
\hline SUC10 & $\begin{array}{l}\text { I improved/increased the revenues and profits of the family business after the management/leadership } \\
\text { of the business was handed over to me }\end{array}$ \\
\hline
\end{tabular}

*This questionnaire was worded for the successor 